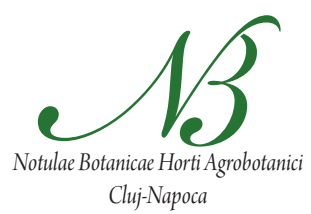

\title{
Antioxidant Activity, Total Phenolics and Taxol Contents Response of Hazel (Corylus avellana L.) Cells to Benzoic Acid and Cinnamic Acid
}

\author{
Ebrahim BEMANI, Faezeh GHANATI*, Laleh YOUSEFZADEH \\ BOROUJENI, Faezeh KHATAMI \\ Tarbiat Modares University (TMU), Faculty of Biological Science, Department of Plant Biology, 14115-154, Tehran-Iran \\ ghangia@modares.ac.ir ( ${ }^{*}$ corresponding author)
}

\begin{abstract}
Hazel (Corylus avellana L.) plant has been recently introduced as a plant with the ability to produce Taxol. In the present research effects of different concentrations of benzoic acid and cinnamic acid on the phenolic compounds, Taxol content, and antioxidant activity of extracts of suspension-cultured hazel cells were investigated. The cells were treated with different concentrations of benzoic acid $(0$, 0.5 , and $1 \mathrm{mM})$ and cinnamic acid $(0,0.15,0.3$ and $0.6 \mathrm{mM})$ on day 7 of subculture and were harvested on day 14 . Benzoic acid in higher concentrations increased Taxol ( 4 fold of the control) and antioxidant activity of the cell extract. Cinnamic acid supply did not bring remarkable increase in Taxol content but increased phenolic contents and antioxidant activity of hazel cells extract. Interestingly, the extract of hazel cells showed more cytotoxicity for human cancer cells than pure Taxol. Further investigations may suggest the extract of cinnamic- and benzoic acid- fed hazel cells for treatment of cancer cells.
\end{abstract}

Keywords: antioxidant activity, benzoic acid, cancer cells, cinnamic acid, Corylus avellana, taxol

\section{Introduction}

Taxol (paclitaxel) is a diterpenoid alkaloid which was first isolated from the bark of pacific yew, Taxus brevifolia (Wani et al., 1971). Paclitaxel is currently one of the best known drug approved for use in the treatment of breast, ovarian and non-small cell lung cancer and AIDS-treated Kaposi's sarcoma (Ojima et al., 2002). A problem with the extraction of Taxol from yew tree is the fact that yew is a rare, endangered tree which grows very slowly, its Taxol yield is very low, and extraction process is time consuming and expensive too (Kingston, 1994). The increasing demand for Taxol supply has provoked an ecological argument about possible devastation of natural yew resources thus leading to the search for new alternative approaches, among which establishment of Taxol producing cell cultures is one of the most extensively explored areas. Hazel (Corylus avellana) is an individual plant among angiosperms which has been reported to be able to produce Taxol and other taxanes (Bestoso et al., 2006; Hoffman et al., 1998; Otaggio et al., 2008). The main benefit of producing taxanes by hazel cell cultures is that hazel is widely available, fast growing in vivo, and easier to cultivate in vitro than yew (Bestoso et al., 2006). The accumulation of many secondary metabolites such as phytoalexins is widely recognized as part of plant cell defense response to various biotic and abiotic elicitors. Therefore, the application of elicitors has been one of the most effective strategies for improving the productivity of paclitaxel and many other useful secondary metabolites in plant cell cultures (Roberts and Shuler, 1997). Efforts to increase production of certain products by adding ingredients to the medium have been effective in many cases as well. Benzoic acid (BA) is one of precursor of Taxol and addition of it to the medium of Taxus cells resulted in enhanced content of Taxol (Fett-neto et al., 1994; Fleming et al., 1994). Phenylalanine (Phe) is an amino acid which is involved in the synthesis of side chain of Taxol (Jennewein and Croteau, 2001). Addition of Phe to the medium of Taxus calli resulted in enhanced content of Taxol (Fett-neto et al., 1994). Phenylalanine is converted to cinnamic acid (CA) through deamination derived by phenylalanine ammonia lyase (PAL). Cinnamic acid is also the main precursor of phenolics metabolism pathway. Phenolic compounds are major non enzymatic components of antioxidant system of plants (Rafat $e t$ al., 2010) and there is a relationship between phenolics content and antioxidant activity of plant cells (Gao et al., 2006). The present study was undertaken in order to evaluate the effects of feeding of suspension-cultured hazel cells with different concentrations of BA and CA on the production of Taxol and the antioxidant and cytotoxic effects of hazel cells extract.

\section{Materials and methods}

\section{Cell culture and treatments}

A rapid growing cell line of Corylus avellana was used (Rezaei et al., 2011). Treatments of suspension-cultured cells were conducted on day 7 by adding $0,0.5$, and $1 \mathrm{mM}$ of benzoic acid and $0,0.15,0.3$ and $0.6 \mathrm{mM}$ of cinnamic acid to cultures. The cells were allowed to continue to grow for further 1 week. Fourteen days old cells were harvested, 
70

dried and their extract was assessed for intracellular Taxol. The filtrate was also used for assessment of extracellular Taxol.

\section{Extraction and quantification of Taxol}

Taxol was extracted from medium and powdered dried cells by methods previously described by Wu and Lin (2003) with some modifications. In brief, the dried cells were pulverized and suspended in $10 \mathrm{~mL}$ methanol, filtered, and the filtrate was air-dried then re-dissolved in dichloromethane: water $(1: 1, \mathrm{v} / \mathrm{v})$ followed by centrifugation at $5000 \mathrm{rpm}$. Dichloromethane phase was collected, air-dried and re-dissolved in $100 \mu \mathrm{L}$ methanol (HPLC grade) and filtered passing through a $0.45 \mu \mathrm{m}$ syringe filter, before being injected to HPLC. The Taxol content of the extracts was quantified by HPLC system (Knauer, Germany), equipped with a C-18 column (Perfectsil Target ODS3, $5 \mu \mathrm{m}, 250 \times 4.6 \mathrm{~mm}$, MZ-Analysentechnik, Mainz, Germany). Taxol was eluted with a linear gradient of acetonitrile and water (45:55) at a flow rate of $1 \mathrm{~mL} \mathrm{~min}$ ${ }^{1}$ and was detected at $227 \mathrm{~nm}$ using a UV detector (PDA, Germany). Identification of Taxol was accomplished by comparison of retention times with authentic standard.

\section{Evaluation of cytotoxicity of hazel cells extract on cancer} cells

The liver carcinoma cells (HepG2) was obtained from the Pasteur institute of Iran and was cultured in RPMI 1640 medium (Gipco, Grand Island, N.Y), supplemented with $10 \%$ fetal bovine serum, 100 Units $/ \mathrm{mL}$ penicillin and $100 \mu \mathrm{g} / \mathrm{mL}$ streptomycin. The cells were incubated at $37^{\circ} \mathrm{C}$ under $5 \%$ of $\mathrm{CO}_{2}$ and were sub-cultured every 4 days. The morphology of HepG2 cells was checked with inverted microscope (Nikon TE-2000, Japan) before and after the treatments. Cytotoxic effects of Taxol and hazel cells extract were monitored by MTT colorimetric assay (Cai et al., 2010). Briefly, $100 \mu \mathrm{L}$ of MTT solution (5mg/ $\mathrm{mL}$ PBS) was added to HepG2 cell cultures followed by incubation at $37^{\circ} \mathrm{C}$ under $5 \% \mathrm{CO}_{2}$, for $4 \mathrm{~h}$ allowing to formation of formazan crystals. Then upper solutions were removed and $250 \mu \mathrm{L}$ of dimethyl sulfoxide (DMSO) was added to each sample in order to dissolve formazan crystals. After $30 \mathrm{~min}$, equivalent volumes of upper solutions were transferred to 96-well plate of Elisa Reader (Anthuos 2020, Australia) and absorbance of samples was measured at $492 \mathrm{~nm}$. Cytotoxicity was determined by assessment of density of live cells according to the following formula

$\%$ viability of cancer cells $=[$ (absorbance of controlabsorbance of test sample)/absorbance of control] $\times 100$

Determination of phenolic compounds, reducing power, and free radical scavenging capacity

Aliquots of dried cells $(3 \mathrm{~g})$ were pulverized and suspended in $50 \mathrm{~mL}$ of methanol followed by centrifugation at $4000 \mathrm{rpm}$. The supernatant was collected; air dried and the dried material $(50 \mathrm{mg})$ was re-dissolved in $5 \mathrm{~mL}$ of methanol and used for determination of phenolic com- pounds, free radical scavenging capacity, and reducing power assay.

Phenolic compounds were quantified using FolinCiocalteu method (Chua et al., 2007). Briefly $0.5 \mathrm{~mL}$ of methanolic extract was mixed with $0.5 \mathrm{~mL} 0.1 \mathrm{~N}$ FolinCiocalteu reagent (Sigma, USA). The mixture was kept within $2-5 \mathrm{~min}$, followed by the addition of $1.0 \mathrm{~mL}$ of $20 \%$ $\mathrm{Na}_{2} \mathrm{CO}_{3}$. After 10 min of incubation at ambient temperature, the mixture was centrifuged at $12,000 \times \mathrm{g}$ for $8 \mathrm{~min}$. The absorbance of the supernatant was measured at 730 nm using spectrophotometer (Cintra 6, GBC, Australia). The results were expressed as gallic acid equivalents per milliliter of extracts.

Reducing power was determined by the assay that described by Oyaizu (1986). In brief, $1 \mathrm{~mL}$ of methanolic cell extract was mixed with $1.25 \mathrm{~mL}$ of $1 \%$ potassium ferricyanide. The mixture was incubated at $50^{\circ} \mathrm{C}$ for $20 \mathrm{~min}$ and then $1.25 \mathrm{~mL}$ of $10 \%$ Trichloroacetic acid was added to the mixture followed by centrifugation at 3,000 rpm for $10 \mathrm{~min}$. The supernatant $(1.25 \mathrm{~mL})$ was mixed with distilled water $(1.25 \mathrm{~mL})$ and ferric chloride solution $(0.1 \%$, $0.25 \mathrm{~mL}$ ). The absorbance was measured at $700 \mathrm{~nm}$. Ascorbic acid at concentration of $10 \mathrm{mg}$. $\mathrm{mL}^{-1}$ was used as positive control.

Free radical scavenging capacity of methanolic extracts was determined using the stable 2.2'diphenylpicrylhydrazyl radicals (DPPH) with some modifications (Maikai et al., 2010). Initially $0.002 \% \mathrm{DPPH}$ was dissolved in methanol and $1.5 \mathrm{~mL}$ of this solution was added to $0.5 \mathrm{~mL}$ of methanolic cell extract. The solution mixture was kept in dark at ambient temperature for $30 \mathrm{~min}$, and then its absorbance was measured at $517 \mathrm{~nm}$ against a blank of 1.5 $\mathrm{mL}$ of $0.002 \% \mathrm{DPPH}$ solution. Ascorbic acid $(10 \mathrm{mg}$. $\mathrm{mL}$ $\left.{ }^{1}\right)$ was used as positive control. The capacity of cell extract to scavenge free radicals was calculated as follows:

Free radical scavenging capacity $(\%)=[$ (absorbance of blank-absorbance of sample)/absorbance of blank $] \times 100$

\section{Statistical analysis}

All observations and experiments were repeated 3 times with 3 independent replicates. Data were then evaluated with one-way analysis of variance combined with Tukey's multiple-comparison test (SigmaStat, SPSS Science, Chicago, IL). Differences between groups were considered significant at the $p<0.05$ level. Results were expressed as mean values \pm standard deviation (SD).

\section{Results and discussion}

Effect of different concentrations of $\mathrm{BA}$ and $\mathrm{CA}$ on the growth of hazel cells is shown in Fig. 1. The results showed that $1 \mathrm{mM}$ of BA significantly decreased dry weight while $0.5 \mathrm{mM}$ of BA did not affect growth of hazel cells (Fig. 1A). Treatment of the cells with CA had no significant effect on their growth (Fig. 1B).

Effects of different concentrations of BA and CA on the contents of intracellular (cell-associated) and extracel- 
Tab. 1. Taxol content of Corylus avellana L. cells treated with different concentrations of BA and CA. Data are presented as the means \pm SD with $n=3$

\begin{tabular}{ccccc}
\hline \multirow{2}{*}{$\begin{array}{c}\text { Treatments } \\
(\mathrm{mM})\end{array}$} & \multicolumn{3}{c}{ Taxol content $(\mu \mathrm{g} / \mathrm{g} \mathrm{DW})$} \\
\cline { 2 - 5 } & 0 & Intracellular & Extracellular & Total \\
\hline \multirow{3}{*}{ BA } & 0.5 & $4.12 \pm 0.6$ & $2.11 \pm 0.7$ & 4.23 \\
& 1 & $7.1 \pm 0.7^{*}$ & $8.59 \pm 1.3^{*}$ & 15.69 \\
& 0 & $2.12 \pm 0.4$ & $2.11 \pm 0.9$ & 4.23 \\
& 0.15 & $1.94 \pm 0.1$ & $1.35 \pm 0.6$ & 3.29 \\
CA & 0.3 & $1.89 \pm 0.4$ & $2.05 \pm 0.2$ & 3.94 \\
& 0.6 & $2.82 \pm 0.3$ & $2.37 \pm 0.1$ & 5.19 \\
\hline
\end{tabular}

* significant at 0.05 probability levels. Data are presented as the means \pm SD with $n=3$
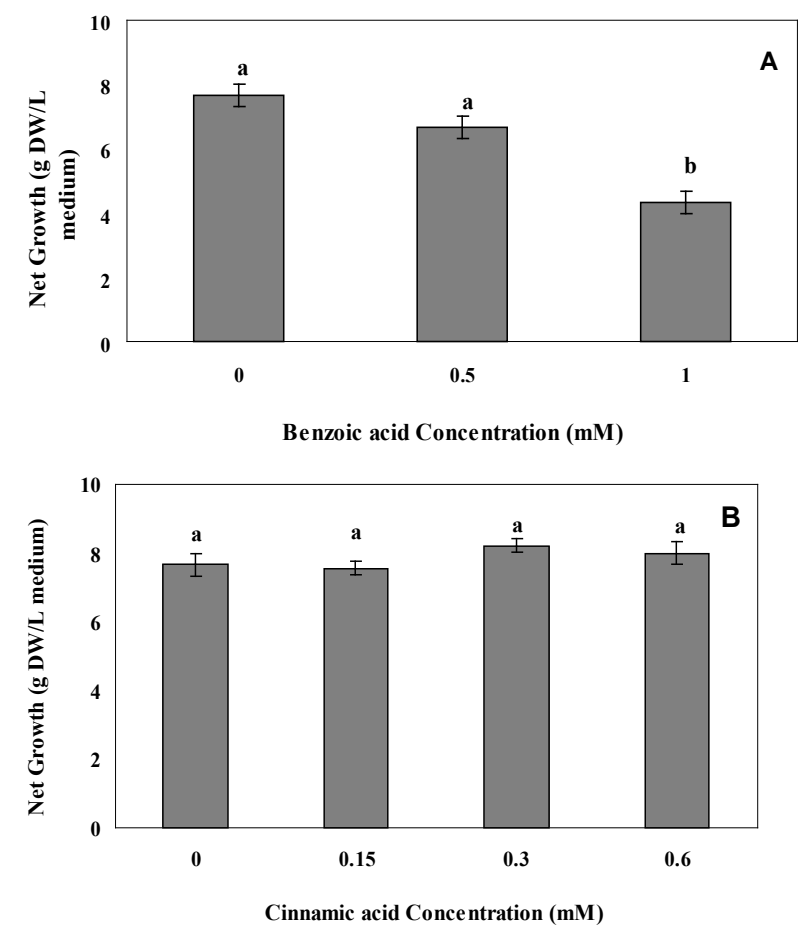

Fig. 1. Growth of hazel cells treated with different concentrations of BA (A) and CA (B). Data are presented as the means \pm $S D$ with $n=3$. Means followed by the same letter are not significantly different at the $p<0.05$ level

lular (released to the medium) of Taxol are shown in Tab. 1. Benzoic acid at concentrations of 0.5 and $1 \mathrm{mM}$ remarkably increased Taxol production by hazel cells so that intracellular and extracellular Taxol contents of $1 \mathrm{mM} \mathrm{BA-}$ treated cells were respectively 3.5 and 2.5 times higher than those of the control cells. Cinnamic acid however, had no significant effect on Taxol production of hazel cells.

The effect of hazel cell extracts on the morphology of HepG2 cells and damage of the HepG2 cells after exposure to hazel cells extract are shown in Fig. 2. The results of MTT assay showed that both standard Taxol and hazel cell extracts inhibited the growth of cancer cells (Fig. 3). Interestingly, viability of cancer cells was much affected by

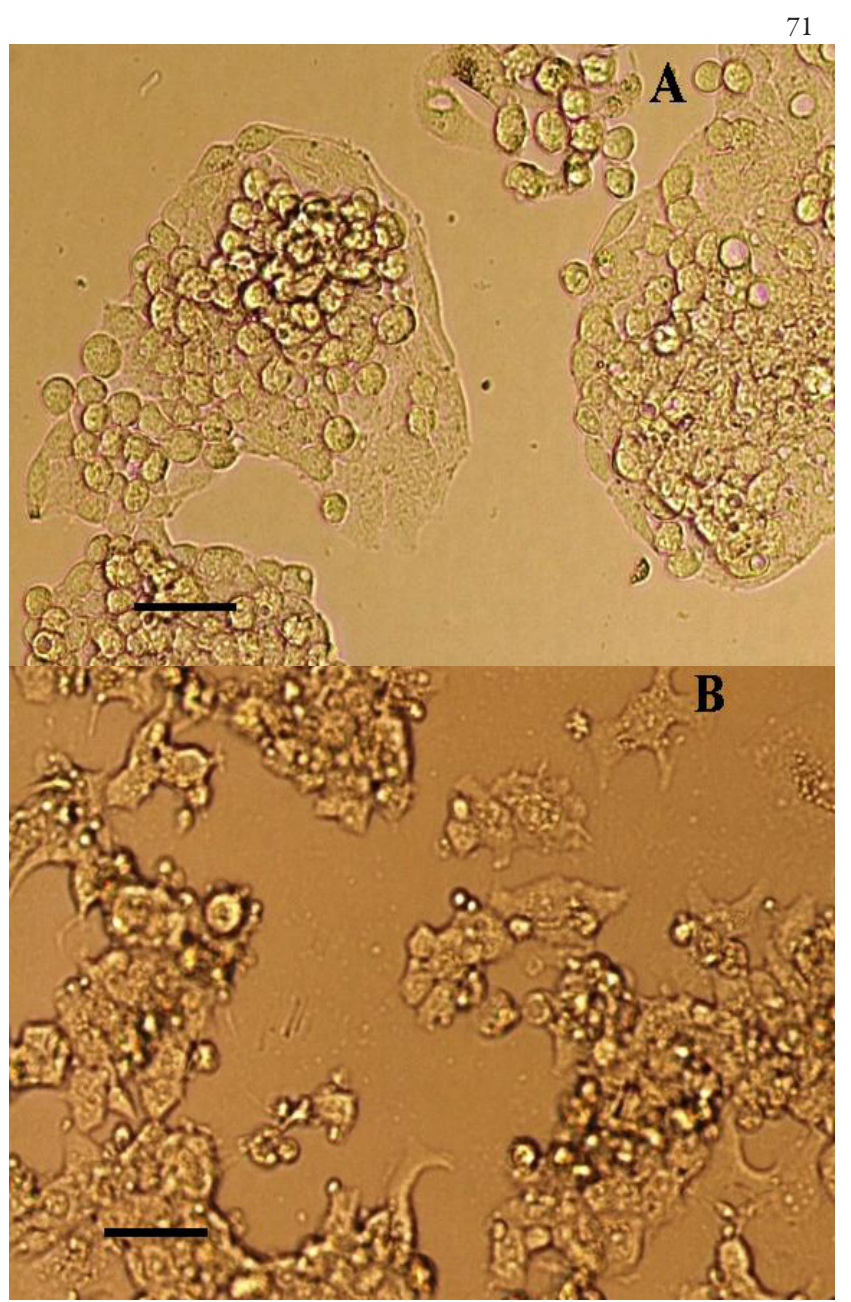

Fig. 2. Morphology of HepG2 cells before (A) and after exposure to hazel cells extract (B), Scale bars $100 \mu \mathrm{m}$

the cell extracts even when their Taxol content was identical to that of the standard, pure Taxol.

The level of Phenolic compounds significantly increased with high concentrations of BA $(1 \mathrm{mM})$ and CA (0.3 and $0.6 \mathrm{mM})$, compared to those of the control cells (Fig. 4). Consequently, free radicals scavenging and reducing power of hazel cells significantly increased at $1 \mathrm{mM} \mathrm{BA}$ and 0.3 and $0.6 \mathrm{mM} \mathrm{CA}$, in comparison with the control cells (Fig. 5 and 6).

Inhibitory effects of BA on the growth of molds have been widely used as a preservation method in food industry. In the present study treatment of hazel cells with BA at high concentration adversely affected the growth but increased the content of phenolics and Taxol of the cells, suggesting that $1 \mathrm{mM}$ of BA is toxic for the cells and in this condition the cells shift their energy expenditure to the biosynthesis of secondary metabolites than to the growth. Regarding to the fact that BA is one precursor for Taxol biosynthesis and participates in biosynthesis of its side chain (Fleming et al., 1994), increase of Taxol in BA-treated cells is expectable. Taxol was found in almost equivalent quantities of intra- and extracellular, showing that the growing medium of hazel cells also can be used as a pool for extraction of Taxol. 


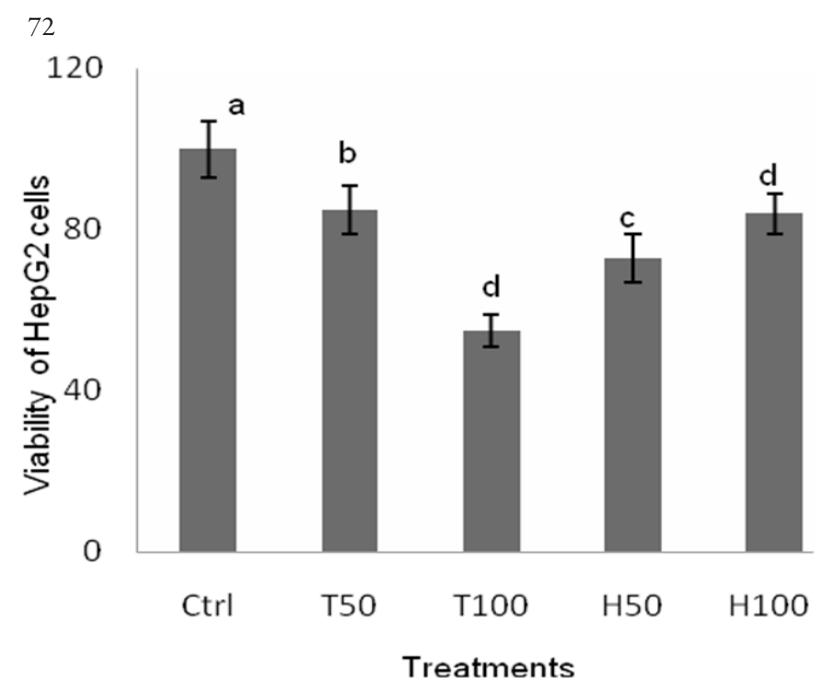

Fig. 3. Comparison of MTT assay in HepG2 cells treated with Taxol and hazel cells extract. Data are presented as the means \pm $\mathrm{SD}$ with $\mathrm{n}=3$. Means followed by the same letter are not significantly different at the $p<0.05$ level. T50 and T100 refer to 50 and $100 \mathrm{nM}$ of standard Taxol, and H50 and H100 refer to hazel cell extracts containing 50 and $100 \mathrm{nM}$ Taxol, respectively, in tandem
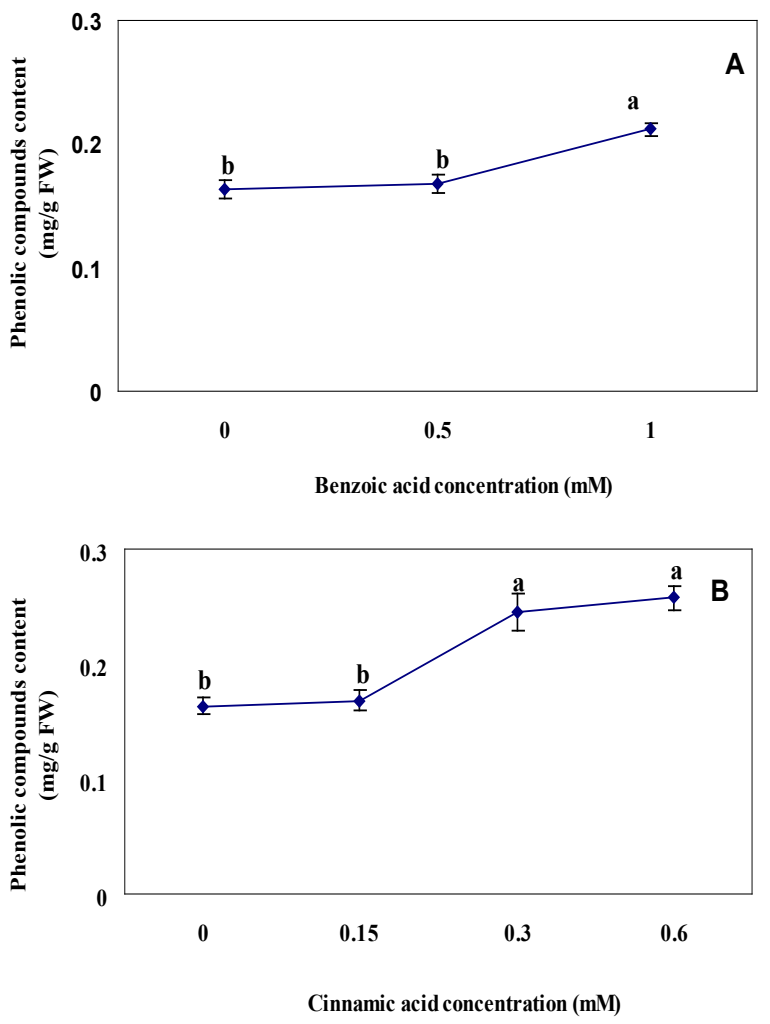

Fig. 4. Phenolic compounds of hazel cells treated with different concentrations of BA (A) and CA (B). Data are presented as the means $\pm S D$ with $n=3$. Means followed by the same letter are not significantly different at the $p<0.05$ level

Cinnamic acid did not alter Taxol production by hazel cells, but increased their phenolics content. It is usually accepted that CA inhibits the activity of PAL (Sato et al.,
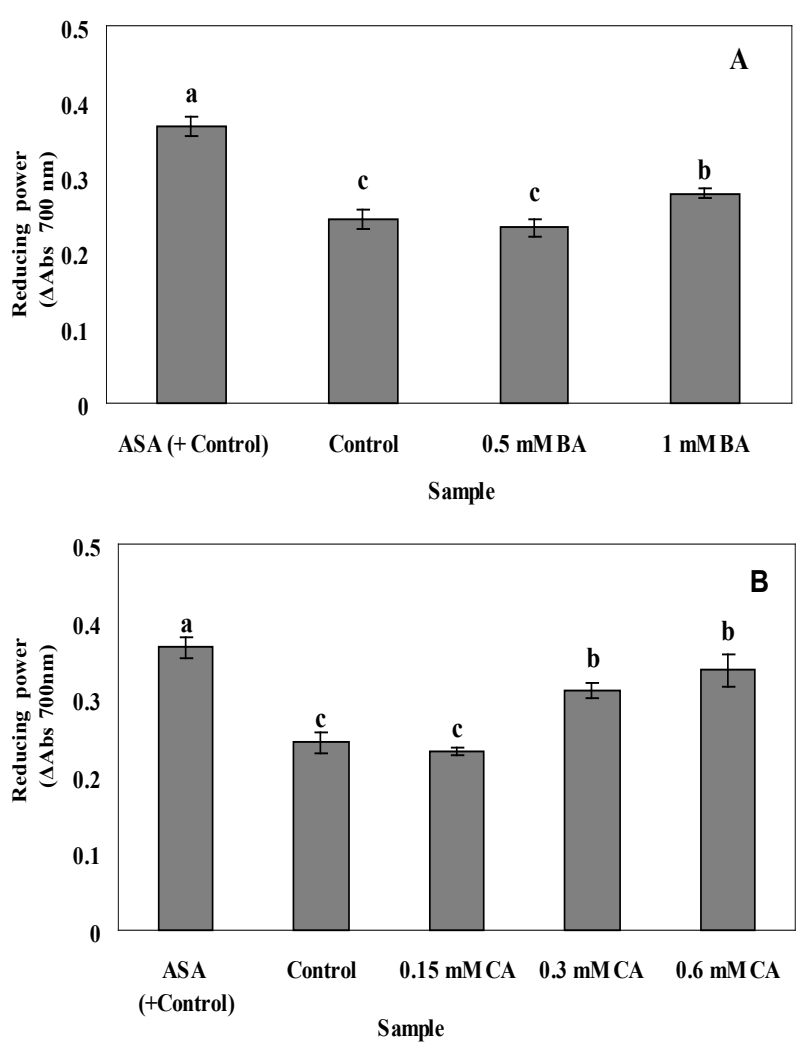

Fig. 5. Reducing power of hazel cells extract treated with different concentrations of BA (A) and CA (B). Ascorbic acid at concentration of $10 \mathrm{mg}$. $\mathrm{mL}^{-1}$ was used as positive control. Data are presented as the means $\pm S D$ with $n=3$. Means followed by the same letter are not significantly different at the $p<0.05$ level 1982), however based on the results presented here it is more likely that CA, up to $0.6 \mathrm{mM}$, was not sufficient to inhibit PAL activity thereby reduce phenolic contents.

Cytotoxicity of Taxol and other Taxans in hazel cells extract has been reported previously (Bestoso et al., 2006). Damage of HepG 2 cells and decrease of their viability in the present research suggest that extract of hazel cells can be used as an alternative remedy for liver carcinoma. This is noteworthy in particular regard to high antioxidant activity of hazel cell extracts and their capacity to reduce $\mathrm{Fe}^{3+} /$ ferricyanide complex as well. These abilities may be, at least in part, of relevance for high quantities of electron donating compounds e.g., phenolics in hazel cells extract (Kalpna et al., 2010; Kosinska and Karamac, 2006). The results presented here demonstrated that antioxidant activity and free radical scavenging capacity of hazel cell extracts were correlated with their phenolics content.

\section{Conclusions}

In conclusion, the results of present research suggest that the application of BA to hazel cell cultures can be a good method to increase production of Taxol by these cells. Feeding of hazel cells with higher concentrations of $\mathrm{BA}$ and CA resulted in higher phenolics content as well as 

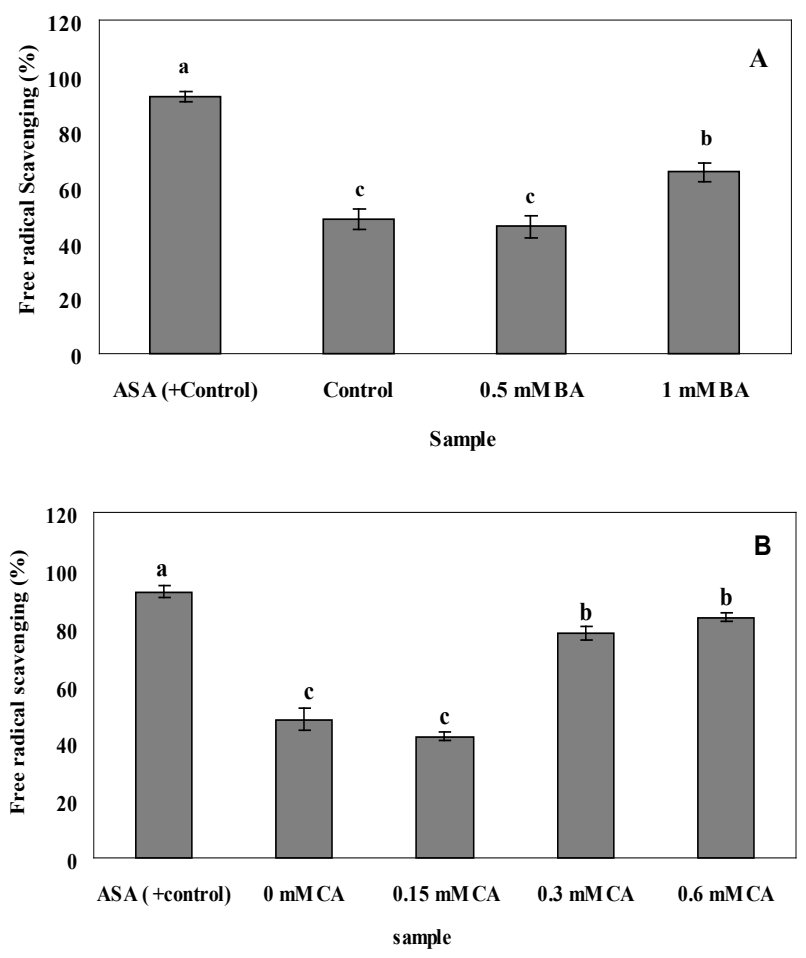

Fig. 6. Free radical scavenging capacity of hazel cells extract treated with different concentrations of BA (A) and CA (B). Ascorbic acid at concentration of $10 \mathrm{mg}^{\mathrm{mL}} \mathrm{m}^{-1}$ was used as positive control. Data are presented as the means $\pm S D$ with $n=3$. Means followed by the same letter are not significantly different at the $p<0.05$ level

higher antioxidant capacity of their extracts. Complementary investigations may suggest remedy of human cancers by the extract of BA- and CA-fed hazel cells which meanwhile provides the body with the advantage of decrease of detrimental effect of free radicals in non cancerous cells.

\section{Acknowledgments}

This work was supported by grant NO 89004358 from National Iran Science Foundation (NISF) to FGH on Investigation about Taxol production by Hazel cells.

\section{References}

Bestoso F, Ottaggio L, Balbi A, Damonte G, Degan P, Mazzei Cavalli F, Ledda B, Miele M (2006). In vitro cell cultures obtained from different explants of Corylus avellana produce Taxol and taxanes. BMC Biotech 6:45-48.

Cai XX, Luo E, Yuan Q (2010). Interaction between Schwann cells and osteoblasts in vitro. Int J Oral Sci 2:74-81.

Chua MT, Tung YT, Chang ST (2007). Antioxidant activities of ethanolic extracts from the twigs of Cinnamum osmophloeum. Bioresource Technol 99:1918-1925.

Fett-neto AG, Melasan SJ, Nicholson SA (1994). Improved Taxol yield by aromatic carboxylic acid and amino acid feeding to cell culture of Taxus cuspidata. Biotechnol Bioeng 44:967-971.
Fleming PE, Floss FG, Haertel M, Knaggs AR, Lansing A, Mocek U, Walker KD (1994). Biosynthetic studies on Taxol. Pure Appl Chem 66:2045-2048.

Gao H, Shupe TF, Hse CY, Eberhardt TL (2006). Antioxidant activity of extracts from the bark of Chamaecyparis lawsoniana (A. Murray) Parl. Holzforschung 60:459-462.

Hoffman A, Khan W, Worapong J, Strobel G, Griffin D, Arbogast B, Barofsky D, Boone RB, Ning L, Zheng P, Daley $P$ (1998). Bioprospecting for Taxol in Angiosperm plant extracts. Spectrosc 13:22-32.

Jennewein S, Croteau R (2001). Taxol: biosynthesis, molecular genetics, and biotechnological applications. Appl Microbiol Biotechnol 57:13-19.

Kalpna R, Mital K, Sumitra C (2010). Vegetable and fruit peels as a novel source of antioxidants. J Med Plants Res 5:63-71.

Kingston DGI (1994). Taxol: the chemistry and structureactivity relationships of a novel anticancer agent. Trends Biotechnol 12:222-227.

Kosinska A, Karamac M. (2006). Antioxidant capacity of roasted health-promoting products. Pol J Food Nutr Sci 15:193-198.

Maikai VA, Kobo PI, Maikai BVO (2010). Antioxidant properties of Ximenia americana. Afr J Biotechnol 9:77447746.

Ojima I, Geney R, Ungureanu IM, Li D (2002). Medicinal chemistry and chemical biology of new generation taxane antitumor agents. IUBMB Life 53:269-274.

Otaggio L, Bestoso F, Armirotti A, Balbi A, Damonte G, Mazzei M, Sancandi M, Miele M (2008). Taxanes from shells and Leaves of Corylus avellana. J Nat Prod 7:58-60.

Oyaizu M (1986). Studies on product browning reaction prepared from glucosamine. J Nutri 44:307-315.

Rafat A, Koshy P, Sekaran M (2010). Antioxidant potential and content of phenolic compounds in ethanolic extracts of selected parts of Andrographis Paniculata. J Med Plants Res 4:197-202.

Rezaei A, Ghanati F, Behmanesh M, Mokhtari-Dizaji M (2011). Ultrasound potentiated salicylic acid-induced physiological effects and production of Taxol in hazelnut (Corylus avellana L.) cell culture. Ultrasound Med Biol 37:1938-1947.

Roberts SG, Shuler ML (1997) Large-scale plant cell culture. Curr Opin Biotech 8:154-159.

Sato T, Kiuchi F, Sankawa U (1982). Inhibition of phenylalanine ammonia-lyase by cinnamic acid derivatives and related compounds. Phytochem 21:845-850.

Wani MC, Taylor HL, Wall ME, Coggon P, McPhail AT (1971). Plant antitumor agents. VI. The isolation and structure of Taxol, a novel antileukemic and antitumor agent from Taxus brevifolia. J Am Chem Soc 93:2325-2327.

Wu J, Lin L (2003). Enhancement of taxol production and release in Taxus chinensis cell cultures by ultrasound, methyl jasmonate and in situ solvent extraction. Appl Microbiol Biotechnol 62:151-155. 